\title{
POTENT ESTROGENIC FLAVONE GLYCOSIDES FROM ATRIPLEX SEMIBACCATA
}

\author{
Kamel H. Shaker ${ }^{* 1}$ and M. M. Mostafa ${ }^{2}$ \\ ${ }^{1}$ National Research Centre, Lab. of Natural Products, Dokki, Cairo, Egypt \\ ${ }^{2}$ Department of Medicinal Chemistry, Faculty of Pharmacy, Menia University, Menia, Egypt
}

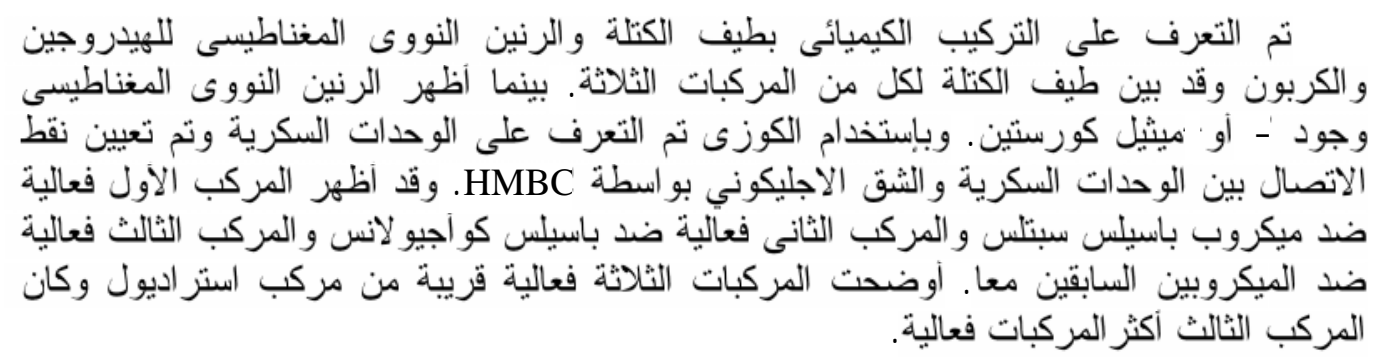

Three known flavone glycosides 1, 2, and 3 were isolated for the first time from the whole plant of Atriplex semibaccata. The assignment of the NMR signals was performed by means of ${ }^{1} \mathrm{H}^{1}{ }^{\mathrm{H}} \mathrm{COSY}, \mathrm{HMQC}$, and HMBC experiments. The isolated compounds showed potent estrogenic, and promising anti-microbial activities.

\section{INTRODUCTION}

Atriplex

semibaccata,

family

(Chenopodiaceae) is very common in salty desert, prostrate or ascending herb with up to $60 \mathrm{~cm}$, leaves thin, up to $4 \mathrm{~cm}^{1}$. It is a very important forage at sheep breading in Australia. Most reports say that no members of this genus contains toxins and that all have more or less edible leaves. However, one report say that if very large quantities are eaten they can cause photosensitivity. ${ }^{2}$ A few leaves of strongerflavoured plants of Atriplex patula can be added to enhance the tast ${ }^{3}$ and its seeds can be used as laxative and the whole plant cures headaches, wandering pains, and the first attacks of rheumatism. ${ }^{4}$ In a previous investigation for Atriplex semibaccata four saponins were isolated. ${ }^{5}$ This paper describes the isolation and structure elucidation of three flavone glycosides $\mathbf{1}, \mathbf{2}$, and $\mathbf{3}$ in addition to, their potent estrogenic and anti-microbial activities.

\section{EXPERIMENTAL}

\section{General}

Negative ion MS: MAT 8500 (Finnigan), matrix glycerol. NMR: $500.13 \mathrm{MHz}\left({ }^{1} \mathrm{H}\right)$ and 125.76 $\mathrm{MHz}\left({ }^{13} \mathrm{C}\right)$, reverse probehead, $\delta$ at ppm, solvent $\mathrm{CD}_{3} \mathrm{OD}, \mathrm{CD}_{3} \mathrm{OD}$ signal were used as int. standard $\left({ }^{1} \mathrm{H}: 3.30,{ }^{13} \mathrm{C}: 49.0\right)$, temp. 290 K, HMQC: phase-sensetive using TPPI, BIRD sequence, GARP decoupled, HMBC: using TTPI, delay to achieve long range couplings: $71 \mathrm{msec}\left(\mathrm{J}_{\mathrm{C}, \mathrm{H}}=14 \mathrm{~Hz}\right)$.

CC: silica gel (0.063-0.2 mm); TLC: silica gel $(0.25 \mathrm{~mm}$ pre-coated plates $60 \mathrm{~F} 254$, Merck, The plates were sprayed with $10 \%$ $\mathrm{H}_{2} \mathrm{SO}_{4}$ in $\mathrm{MeOH}$.

\section{Isolation}

Atriplex semibaccata was collected in 1999 near Burg El-Arab, Alexandria, Egypt and identified by Dr. M. El-Gebaly from the National Research Centre (NRC) Cairo. A Voucher specimen of the plant is deposited at the Herbarium of the NRC, Department of Chemotaxanomy. Dried powder of the whole plant of Atriplex semibaccata (3 $\mathrm{kg}$ ) was exhaustively extracted with $80 \% \mathrm{MeOH}$ to give 
$50 \mathrm{~g}$ methanolic extract. The methanolic extract was successively partitioned between $\mathrm{H}_{2} \mathrm{O}$ and n-hexan, chloroform, and n-butanol. The butanolic fraction was evaporated under red. pressure at $45^{\circ}$ to obtain $7 \mathrm{~g}$ crude butanol extract. The butanolic extract was chromatographed on silica gel column $(1 \mathrm{~m} \mathrm{x}$ $5 \mathrm{~cm}$ ) eluting with $\mathrm{CHCl}_{3}-\mathrm{MeOH}-\mathrm{H}_{2} \mathrm{O}$ in the order of increasing the polarity to afford flavone glycosides fraction $F_{2}(1 \mathrm{~g}) . F_{2}$ was subjected to MPLC using RP-18 material and $\mathrm{MeOH}-\mathrm{H}_{2} \mathrm{O}$ (4:6) then sephadex LH-20 using $\mathrm{MeOH}$ to give flavone glycosides $1(5 \mathrm{mg}), 2$ (10 mg), 3 (4 mg).

\section{Spectral data}

Compound $1 \quad\left(\mathrm{C}_{28} \mathrm{H}_{32} \mathrm{O}_{16}\right)$, $\mathrm{Mr}$ 624); LSI/MS, negative ion mode $\mathrm{m} / \mathrm{z}$ (rel. int.): 623 [M-1] $]^{-}$(83), 477 [M-1-146] $]^{-}$(33), 315 [M-1146-162] ${ }^{-}$(100). ${ }^{13} \mathrm{C}-\mathrm{NMR}$ (Table 1). ${ }^{1} \mathrm{H}-\mathrm{NMR}$ $\left(\mathrm{CD}_{3} \mathrm{OD}\right) \delta$ ppm: $6.15(1 \mathrm{H}, \mathrm{d}, \mathrm{J}=1.8 \mathrm{~Hz}, \mathrm{H}-6)$, $6.35(1 \mathrm{H}, \mathrm{d}, \mathrm{J}=1.8 \mathrm{~Hz}, \mathrm{H}-8), 7.98(1 \mathrm{H}, \mathrm{d}, \mathrm{J}=$ $1.8 \mathrm{~Hz}, \mathrm{H}-2$ '), 6.9 (1H, d, J= 8.4 Hz, H-5'), 7.6 $(1 \mathrm{H}, \mathrm{dd}, \mathrm{J}=8.4,1.8 \mathrm{~Hz}, \mathrm{H}-6$ ') $5.17(1 \mathrm{H}, \mathrm{d}, \mathrm{J}=$ $7.7 \mathrm{~Hz}, \mathrm{H}-1$ ' '), $3.76(1 \mathrm{H}, \mathrm{H}-2$ '”), $3.4(1 \mathrm{H}, \mathrm{H}-$ 3'”), 3.2 (1H, H-4"), 3.5 (1H, H-5"), 3.6/3.7 (2H, H-6"), 4.5 (1H, broad, H-1"'), 3.5 (1H, H2"'), 3.4 (1H, H-3"'), 3.2 (1H, H-4"”), 3.49 (1H, H-5"'), 1.13 (3H, Me), $3.91(\mathrm{OMe})$.
Compound $2 \quad\left(\mathrm{C}_{33} \mathrm{H}_{40} \mathrm{O}_{20}\right), \quad \mathrm{Mr}$ 756); LSI/MS, negative ion mode $\mathrm{m} / \mathrm{z}$ (rel. int.): 755 $[\mathrm{M}-1]^{-}$(100), 623 [M-1-132] (17). ${ }^{13} \mathrm{C}-\mathrm{NMR}$ (Table 1). ${ }^{1} \mathrm{H}-\mathrm{NMR}\left(\mathrm{CD}_{3} \mathrm{OD}\right) \delta \mathrm{ppm}: 6.2(1 \mathrm{H}$, d, J=1.8 Hz, H-6), $6.4(1 \mathrm{H}, \mathrm{d}, \mathrm{J}=1.8 \mathrm{~Hz}, \mathrm{H}-8)$, $8.0\left(1 \mathrm{H}, \mathrm{d}, \mathrm{J}=1.8 \mathrm{~Hz}, \mathrm{H}-2^{\prime}\right), 6.9(1 \mathrm{H}, \mathrm{d}, \mathrm{J}=8.4$ $\mathrm{Hz}, \mathrm{H}-5$ '), 7.6 (1H, dd, J= 8.4, $1.8 \mathrm{~Hz}, \mathrm{H}-6$ '), $5.2(1 \mathrm{H}, \mathrm{d}, \mathrm{J}=7.8 \mathrm{~Hz}, \mathrm{H}-1$ ' '), $3.8(1 \mathrm{H}, \mathrm{H}-2$ ' '), $3.65(1 \mathrm{H}, \mathrm{H}-3$ ' "), 3.73 (1H, H-4"), $3.67(1 \mathrm{H}, \mathrm{H}-$ 5"), 3.55/3.70 (2H, H-6"), 4.5 (1H, broad, H1"'), 3.7 (1H, H-2"'), 3.52 (1H, H-3"'), 3.77 (1H, H-4"'), 3.55 (1H, H-5"'), 1.13 (3H, Me), 4.3 (d, J= 7.4 Hz, H-1"'”), 3.22 (1H, H-2"'"), 3.3 (1H, H-3"'”), 3.46 (1H, H-4"'”), 3.09/3.79 (2H, H-5"'”), 3.90 (OMe).

Compound $\left.3 \quad\left(\mathrm{C}_{33} \mathrm{H}_{40} \mathrm{O}_{20}\right), \quad \mathrm{Mr} \quad 756\right)$; LSI/MS, negative ion mode $\mathrm{m} / \mathrm{z}$ (rel. int.): 755 $[\mathrm{M}-1]^{-}$(9), 623 [M-1-132] $]^{-}$(18). ${ }^{13} \mathrm{C}-\mathrm{NMR}$ (Table 1). ${ }^{1} \mathrm{H}-\mathrm{NMR}\left(\mathrm{CD}_{3} \mathrm{OD}\right) \delta$ ppm: $6.15(1 \mathrm{H}$, d, J=1.8 Hz, H-6), $6.4(1 \mathrm{H}, \mathrm{d}, \mathrm{J}=1.8 \mathrm{~Hz}, \mathrm{H}-8)$, $7.9(1 \mathrm{H}, \mathrm{d}, \mathrm{J}=1.8 \mathrm{~Hz}, \mathrm{H}-2$ '), $6.9(1 \mathrm{H}, \mathrm{d}, \mathrm{J}=8.4$ Hz, H-5'), 7.6 (1H, dd, J= 8.4, $\left.1.8 \mathrm{~Hz}, \mathrm{H}-6^{\prime}\right)$, $5.5(1 \mathrm{H}, \mathrm{d}, \mathrm{J}=7.4 \mathrm{~Hz}, \mathrm{H}-1$ ' '), $3.6(1 \mathrm{H}, \mathrm{H}-2$ ' '), 3.62 (1H, H-3"'), 3.74 (1H, H-4"), 3.18 (1H, H5"), 3.50/3.68 (2H, H-6"), 4.5 (1H, broad, H1"'), 3.53 (1H, H-2"'), 3.42 (1H, H-3"'), 3.17 (1H, H-4"'), 3.33/3.77 (2H, H-5"'), $5.4(1 \mathrm{H}, \mathrm{H}-$ 1'"'), 3.98 (1H, H-2"'), 3.63/3.98 (2H, H-4"'”), 3.59/3.73 (2H, H-5'”'), 3.95 (OMe).<smiles>COc1cc(-c2oc3cc(O)cc(O)c3c(=O)c2O)ccc1O</smiles>

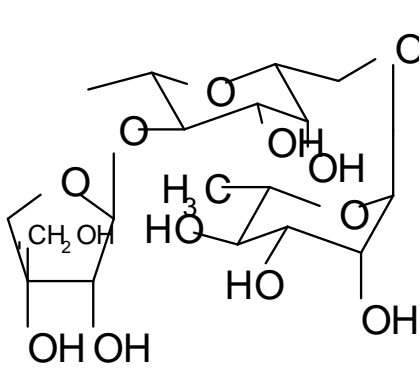

Compound 1

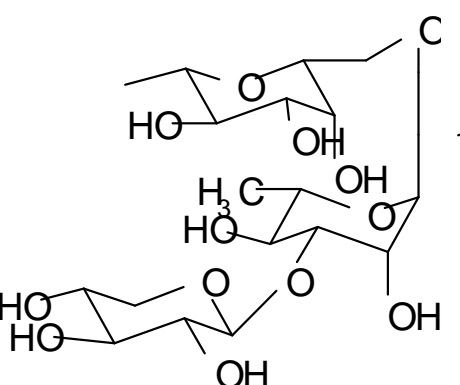

Compound 2<smiles>CC(O)C(O)C(O)C1OC2CCC(OC(C(C)O)C2O)C1O</smiles>

Compound $\mathbf{3}$ 
Table 1: ${ }^{13}$ C-NMR Spectral data for flavone glycosides 1-3.

\begin{tabular}{|c|c|c|c|}
\hline C & 1 & 2 & 3 \\
\hline 2 & 158.7 & 158.9 & 158.8 \\
\hline 3 & 135.5 & 135.5 & 134.5 \\
\hline 4 & 179.3 & 179.2 & 179.2 \\
\hline 5 & 162.8 & 162.9 & 163.0 \\
\hline 6 & 99.9 & 99.9 & 99.8 \\
\hline 7 & 165.9 & 166.0 & 165.8 \\
\hline 8 & 94.9 & 94.8 & 94.8 \\
\hline 9 & 158.3 & 158.4 & 158.4 \\
\hline 10 & 105.5 & 105.7 & 105.9 \\
\hline $1^{\prime}$ & 122.9 & 122.9 & 123.4 \\
\hline 2 ' & 114.5 & 114.6 & 114.6 \\
\hline $3^{\prime}$ & 150.9 & 150.9 & 150.6 \\
\hline 4 ' & 148.4 & 148.4 & 148.3 \\
\hline 5 , & 116.0 & 115.9 & 115.9 \\
\hline 6' & 123.7 & 123.8 & 123.5 \\
\hline \multirow{2}{*}{$\mathrm{OCH}_{3}$} & 56.9 & 56.9 & 57.0 \\
\hline & glucose & galactose & galactose \\
\hline 1" & 104.9 & 104.9 & 100.8 \\
\hline 2, & 73.1 & 73.01 & 79.0 \\
\hline 3, & 78.2 & 75.2 & 75.3 \\
\hline $4^{\prime \prime}$ & 71.6 & 71.7 & 70.4 \\
\hline 5, & 75.4 & 75.7 & 74.8 \\
\hline \multirow[t]{2}{*}{$6^{\prime \prime}$} & 67.3 & 67.9 & 67.2 \\
\hline & rhamnose & rhamnose & rhamnose \\
\hline $1 \%$ & 101.8 & 101.9 & 101.9 \\
\hline $2^{\prime \prime \prime}$ & 72.1 & 71.7 & 72.3 \\
\hline $3^{\prime \prime \prime}$ & 72.2 & 82.3 & 72.6 \\
\hline $4, "$, & 73.8 & 70.1 & 72.4 \\
\hline $5, "$ & 69.9 & 69.5 & 68.4 \\
\hline \multirow[t]{2}{*}{$6, "}$, & 17.9 & 18,0 & 17.9 \\
\hline & & xylose & apiose \\
\hline $1, "$, & & 106.5 & 110.9 \\
\hline $2^{\prime,,}$ & & 75.2 & 77.9 \\
\hline $3,, \%$ & & 77.5 & 80.9 \\
\hline 4,9 & & 71.04 & 75.4 \\
\hline $5,$, & & 66.8 & 66.5 \\
\hline
\end{tabular}

\section{Procedure of the estrogenic assay}

Immature femal sprague-Dawley rats weighing about 55-60 g are ovarectomized, they are kept for about one week on standard laboratory diet and water add libitum. The test compounds 1, 2, and $\mathbf{3}$ are adminestered in $0.5 \%$ solution of carboxy methyl cellulose as subcuteneous injection in various doses 0.02 , 0.1 and $0.5 \mu \mathrm{g} / \mathrm{kg}$ to groups of 10 rats. Doses of $0.02,0.1$ and $0.5 \mu \mathrm{g} / \mathrm{kg}$ estradiol per animal are used as reference standard. The test compounds are dosed twice daily on two following days at 10.00 a.m and 5.00 p.m At 5.00 p.m of the third day and 10.a.m. of the fourth day vaginal smears are taken using cotton swabs moistered with saline. The smears are transferred to a glass slide and stained for 10 minutes with 5\% aqueous methylene blue solution. They are evaluated microscopically according to the following score: 
- Diestrus smear, mainly leucocytes, few epithalia cells.

- Mixture of leucocytes and epithalial cells

- Proestrus smear, nucleated or nucleated plus cornified cells.

- Estrus smear, cornfied cell S only. Only animals showing score 2 or 3 are considered to be positive.

\section{RESULT AND DISCUSSION}

The n-butanol extract of the whole plant of Atriplex semibaccata was obtained as described in experimental part. The n-butanol extract was subjected to column chromatography on silica gel and eluted with chloroform, chloroform-methanol and chloroform-methanol-water to afford main flavonoids fraction. The flavonoid fraction was chromatographed on MPLC using RP-18 and eluted with water-methanol (6:4) to afford three flavonoid glycosides which purified on Sephadex LH-20 using methanol to give compounds $\mathbf{1}, \mathbf{2}$, and $\mathbf{3}$.

The LSI mass spectrum for $\mathbf{1}, \mathbf{2}, \mathbf{3}$ exhibited $[\mathrm{M}-1]^{-}$ion at $\mathrm{m} / \mathrm{z} 623,755,755$. The ${ }^{1} \mathrm{H}$ and ${ }^{13} \mathrm{C}-\mathrm{NMR}$ spectra for the three compounds showed 3'-O-methyl-quercetine as aglycone. ${ }^{6}{ }^{1} \mathrm{H}-\mathrm{NMR}$ for $\mathbf{1}, \mathbf{2}, 3$ showed two singlet at $\delta 6.2,6.4$ for $\mathrm{H}-6$ and $\mathrm{H}-8$ while the signals at $\delta 6.9,7.6$, and 7.9 corresponding to H-5', H-6', and H-2, ${ }^{13} \mathrm{C}-\mathrm{NMR}$ showed the presence of methoxy group C-3' at $\delta 56.9$. The presence of two sugar moieties in compound 1 was confirmed from two anomeric ${ }^{13} \mathrm{C}$ signals at $\delta 104.9$ and 101.8 while compound $\mathbf{2}$ showed three anomeric ${ }^{13} \mathrm{C}$ signals at $\delta 104.9,101.9$, and 106.5 and three anomeric ${ }^{13} \mathrm{C}$ signals of compound $\mathbf{3}$ at $\delta$ 100.8, 101.9, and 110.9 (Table 1). Compounds $\mathbf{1}, \mathbf{2}$ and $\mathbf{3}$ were identified by ${ }^{1} \mathrm{H}-\mathrm{NMR},{ }^{13} \mathrm{C}-\mathrm{NMR}$ data and comparison of the data with reference data. ${ }^{7-9}$ Compound $\mathbf{3}$ was isolated from Pituranthos tortuosus (Apiaceae) Desf, Benth \& Hook $^{8}$ while compound $\mathbf{2}$ isolated from the leaves of Hammada scoparia (Chenopodiaceae). ${ }^{9}$ The presence of galactose moiety in compound $\mathbf{2 , 3}$ instead of glucose was confirmed by the coupling constant of H-3" of galactose (dd, J= 3.2, $9.4 \mathrm{~Hz}$ ) and ${ }^{13} \mathrm{C}-\mathrm{NMR}$ data. Comparison of ${ }^{13} \mathrm{C}$ - data of the sugars with the published data by Atta ur-Rahman ${ }^{10}$ showed a very good agreement (Table 2).

\section{Anti-microbial test}

Anti-microbial activities were tested against, Bacillus subtilis, Bacillus coagulans, Micrococcus sp., Candida albicans, Aspergillus niger, Macrophomena sp., Botrytis $s p$. which obtained from the culture collection of the microbiological laboratory, National Research Centre, Cairo, Egypt. The activity was determined by measuring the inhibition zones using agar plate diffusion methods. ${ }^{11-13}$ The diameter of inhibition zones was measured after $24 \mathrm{hr}$ for bacteria and yaest and $48 \mathrm{hr}$ for moulds. Purified compounds were tested at 1 $\mathrm{mg} / 1 \mathrm{ml}$. The results are shown in (Table 3 ). Compound 1 showed high activity against Bacillus subtilis and no activity against Bacillus coagulans. Compound 2 showed moderate activity against Bacillus coagulans, and low activity against Bacillus subtilis. Compound $\mathbf{3}$ showed high activity against Bacillus coagulans, and Bacillus subtilis. All compounds 1, 2, and $\mathbf{3}$ showed low activity against Micrococcus sp., and Botrytis sp. and no activity against Candida albicans, Aspergillus niger, and Macrophomena sp.

\section{Estrogenic activity}

Flavonoid class have previously been demonstrated to possess estrogenic activity in a number of hormonally responsive systems. ${ }^{14}$ Phytochemists determined that apigenin, diosmetin, and kaempferol had the most potent estrogenic activity, which they deemed "nearly equal to those of the isoflavones diadzein....and genistein. ${ }^{15}$ This study aims to characterize the estrogenic activity of flavonoid glycosides $\mathbf{1 , 2}$ and $\mathbf{3}$.

\section{Name of the method Vaginal Cornification Purpose and rational}

The Allen -Doisy test for vaginal cornification in rodents ${ }^{16}$ is based on the observation of Stockard and Papanicolaou ${ }^{17}$ that reported the cyclic vaginal cornification in guinea pigs. The procedure is described in experimental part.

Evaluation The number of positive animals in each dosage group is recorded. Using various doses, $\mathrm{ED}_{50}$ values can be calculated. The results are shown in Table (4). 
Table 2: ${ }^{13} \mathrm{C}-\delta$ values for sugars (bold refer to substituted positions). ${ }^{10}$

\begin{tabular}{||c|c|c|c|c|c|}
\hline C & $\beta$-D-Glc & $\beta$-D-Gal & $\beta$-D-xyl & $\alpha$-L-Rha & $\beta$-D-api \\
\hline 1 & 105.5 & 101.7 & 106.8 & 101.5 & 109.1 \\
\hline 2 & 75.5 & $\mathbf{7 7 . 8}$ & 74.9 & 71.8 & 77.7 \\
\hline 3 & 78.3 & 73.6 & 78.6 & $\mathbf{8 2 . 7}$ & 80.4 \\
\hline 4 & 72.6 & 71.1 & 71.7 & 72.9 & 75.4 \\
\hline 5 & 75.5 & 76.9 & 67.5 & 69.6 & 65.3 \\
\hline 6 & $\mathbf{6 8 . 8}$ & 61.6 & & 18.5 & \\
\hline
\end{tabular}

$\mathrm{C}=$ carbon atoms of the sugar, $\mathrm{Glc}=$ glucopyranose, $\mathrm{Gal}=$ galactopyranose, $\mathrm{Rha}=$ rhamnopyranose, $\mathrm{xyl}=$ xylopyranose, api $=$ apiofuranose .

Table 3: Anti-microbial activities of the isolated compounds.

\begin{tabular}{|c|c|c|c|c|c|c|c||}
\hline \multirow{2}{*}{ Compound } & \multicolumn{7}{|c||}{ Inhibition Zone Width } \\
\cline { 2 - 8 } & M1 & M2 & M3 & M4 & M5 & M6 & M7 \\
\hline $\mathbf{1}$ & +++ & - & + & - & - & - & + \\
\hline $\mathbf{2}$ & + & ++ & + & - & - & - & + \\
\hline $\mathbf{3}$ & +++ & +++ & + & - & - & - & + \\
\hline
\end{tabular}

+ the activity $<0.5 \quad++$ the activity from 0.6 to 1.0

+++ the activity more than 1.0

M1: Bacillus subtilis, M2: Bacillus coagulans, M3: Micrococcus sp., M4: Candida albicans, M5: Aspergillus niger, M6: Macrophomena sp., M7: Botrytis sp.

Table 4: Estrogenic activities for the isolated compounds 1, 2,3.

\begin{tabular}{|c|c|c|c|c|c|}
\hline \hline Dose & 1 & 2 & 3 & Estradiol & Control \\
\hline $0.02 \mu \mathrm{g} /$ animal & 1 & 1 & 2 & 3 & 0 \\
\hline $0.1 \mu \mathrm{g} /$ animal & 6 & 6 & 7 & 8 & 0 \\
\hline $0.5 \mu \mathrm{g} / \mathrm{animal}$ & 9 & 9 & 9 & 10 & 0 \\
\hline $\mathrm{E} \mathrm{D}_{50}$ & $1.8 \mu \mathrm{g} / \mathrm{kg}$ & $1.8 \mu \mathrm{g} / \mathrm{kg}$ & $1.5 \mu \mathrm{g} / \mathrm{kg}$ & & \\
\hline
\end{tabular}

\section{Conclusions}

The three tested compounds $\mathbf{1}, \mathbf{2}$, and $\mathbf{3}$ showed a potent estrogenic activities nearly to that of estradiol. The most potent one is compound $\mathbf{3}$.

\section{Acknowledgment}

The Authors wish to thank Prof. Dr. K. Seifert, University of Bayreuth, Germany for NMR analysis, and Mrs. Mervat Morsy, National Research Centre, Egypt for antimicrobial measurements.

\section{REFERENCES}

1- V. Tackholm, Student Flora of Egypt, $2^{\text {nd }}$ edition, 1974, p. 114.

2- E. Bolton, Lichens for Vegetable Dyeing, Studio Vista ISBN 0-289-70288-7, (1972).

3- E. Launert, Edible and Medicinal Plants, Hamlyn, ISBN 0-600-37216-2 (1981).

4- M. Grieve, Modern Herbal, Penguin, ISBN 0-14-046-440-9 (1984).

5- H. K. Shaker, K. Dokendorff and K. Seifert, Naturforschung, 58 C, 485 (2003). 
6- K. Agrawal, ${ }^{13}$ C-NMR of Flavonoids, Elsevier Amsterdam (1989).

7- J. B. Harborne and T. J. Mabry, The Flavonoids Advances in Research. Chapman \& Hall, London (1982).

8- S. Abdel-Naser, K. Taha, G. Mahran, Y. Okada, Y. Matsumaru, H. Nishino and T. Okuyama, Natural Medicines 52 (2), 191 (1998).

9- B. Salehe et al., Chem. Pharm. Bull., 50 (9), 1268 (2002).

10- Atta-ur-Rahman, Studies in Natural Products Chemistry, 15 (1995).

11- C. Thornsbery, L. T. Garan and E. H. Gerlach, American Society for Microbiology, Washington, Cumitech, G., New Development in Microbial Agent Susceptibility Testing, in: Manual of Clinical Microbiology (1977).
12- S. C. Edberg, Antibiotic and Infection, Church Livingstone, New York, 1983, pp. 211-223.

13- A. W. Bauer, W. M. M. Kirby and J. C. Sherris, Am. J. Clin. Pathol., 45, 493, (1966).

14- B. M. Collins-Burow, M. E. Burow, B. N. Duong and J. A. McLachlan, Nutr Cancer, 38 (2), 229-44 (2000).

15- M. Yoshikawa, T. Uemura and $\mathrm{H}$. Shimoda, Chem. Pharm. Bull., 48 (7), 1039-1044 (2000).

16- E. Allen and E. A. Doisy, J. Am. Med. Ass., 81, 814-821 (1923).

17- C. R. Stockard and G. N. Papanicolaou, Am. J. Anat., 22, 115-283 (1957). 